\title{
A STUDY OF BUNDLE BRANCH BLOCK AS A PROGNOSTIC INDICATOR IN PATIENTS OF ACUTE MYOCARDIAL INFARCTION
}

\author{
Pashaura Singh Sandhu1, Rajat Kharbanda ${ }^{2}$, Avtar Singh Dhanju³ ${ }^{3}$, Tejinder Sikri, Jagbir Singh ${ }^{5}$, Tarun Bansal6, Saleem Altaf Wani ${ }^{7}$, \\ Sahil Kumar ${ }^{8}$
}

\author{
${ }^{1}$ Assistant Professor, Department of Medicine, GMC, Amritsar. \\ 2Junior Resident, Department of Medicine, GMC, Amritsar. \\ ${ }_{3}^{3}$ Assistant Professor, Department of Medicine, GMC, Amritsar. \\ ${ }^{4}$ Professor, Department of Medicine, GMC, Amritsar. \\ 5Junior Resident, Department of Medicine, GMC, Amritsar. \\ ${ }_{6}^{6}$ Senior Resident, Department of Cardiology, BJMC, Ahmedabad. \\ ${ }^{7}$ Senior Resident, Department of Anaesthesiology, ESI-PGIMSR, New Delhi. \\ $8 J u n i o r$ Resident, Department of Medicine, GMC, Amritsar.
}

\begin{tabular}{l}
\hline ABSTRACT \\
Acute myocardial infarction (AMI) is an event of myocardial necrosis caused by an unstable ischaemic syndrome, appearance of \\
LBBB or RBBB in patients presenting with myocardial infarction predicts adverse long-term cardiovascular outcomes compared to \\
patients without bundle branch block.
\end{tabular}

\section{MATERIALS AND METHODS}

This is a case control observational study. We prospectively studied the clinical, laboratorial, electrocardiographical and twodimensional echocardiographic parameters of around 60 patients including 30 patients of myocardial infarction with bundle branch block (Group A) and 30 patients of myocardial infarction without bundle branch block (Group B) at Government Medical College and Hospital, Amritsar. For statistical significance, the "p value" was calculated and a value $<0.05$ was considered as significant.

\section{RESULTS}

Mean CPK MB (U/L) in patients of AMI with BBB (Group A) was $255.56 \pm 56$ and in patients of AMI without BBB (Group B) was 175 \pm 13.59. In Group A 4 (13.33\%), 8 (33.33\%), 10 (33.33\%) and 8 (26.66\%) presented in Killip class 1, 2, 3 and 4 respectively. In Group B 10 (33.33\%), 12 (40\%), 6 (20\%) and 2 (6.66\%) were in Killip class 1, 2, 3 and 4 respectively. 2D echocardiography revealed that in Group A 21 (70\%) patients had regional wall abnormality and $9(30 \%)$ patients in Group B had regional wall motion abnormality. Mortality in Group A was 9 (21\%) patients as compared to 2 (6.66\%) patients in Group B.

\section{CONCLUSION}

AMI with bundle branch blocks is associated with more in-hospital morbidity and mortality.

\section{KEYWORDS}

Acute Myocardial Infarction, Bundle Branch Block, Arrhythmia, Mortality.

HOW TO CITE THIS ARTICLE: Sandhu PS, Kharbanda R, Dhanju AS, et al. A study of bundle branch block as a prognostic indicator in patients of acute myocardial infarction. J. Evolution Med. Dent. Sci. 2018;7(05):567-570, DOI: 10.14260/jemds/2018/129

\section{BACKGROUND}

Acute myocardial infarction is an event of myocardial necrosis caused by an unstable ischaemic syndrome. ${ }^{1}$ Myocardial ischaemia is characterised by ionic and biochemical alterations, creating an unstable electrical substrate capable of initiating and sustaining arrhythmias and infarction areas of electrical inactivity and blocks conduction, which also promote arrhythmogenesis. ${ }^{2}$ Complete right and left bundle branch block are definite electrocardiographic abnormalities, which suggest the possibility of myocardial damage. ${ }^{3}$

'Financial or Other Competing Interest': None.

Submission 19-11-2017, Peer Review 14-01-2018,

Acceptance 20-01-2018, Published 29-01-2018.

Corresponding Author:

Dr. Rajat Kharbanda,

\#157, G-Block, Girls Hostel,

Government Medical College,

Circular Road, Amritsar-143001, Punjab.

E-mail: meetrajat12@gmail.com

DOI: $10.14260 /$ jemds $/ 2018 / 129$

(c) (i) $(9)$
In patients with acute myocardial infarction, prevalence of right and left bundle branch block are similar. Patients with bundle branch block have more comorbid conditions, are likely to receive therapy and have an increased risk for hospital death compared with patients with no bundle branch block. ${ }^{4}$ Previous studies of patients with AMI and BBB (LBBB and RBBB) at hospital admission, both in prethrombolytic 5,6 and thrombolytic era ${ }^{7-12}$ have reported in general a poor overall prognosis and a high risk for short-term death. This study is conducted to evaluate the incidence of bundle branch block with myocardial infarction and the association of bundle branch blocks with in-hospital mortality and morbidity in patients of acute myocardial infarction.

\section{MATERIALS AND METHODS}

This is a case control observational. A total of 60 patients of acute myocardial infarction admitted in Guru Nanak Dev Hospital attached to Govt. Medical College, Amritsar, out of which 30 patients as case (Group A: Patients of myocardial infarction with bundle branch block) and 30 patients as control (Group B: Patients of myocardial infarction without 
bundle branch block) were enrolled in this study. Patients above 18 years of age with ST segment elevation are included and patients with previous myocardial infarction are excluded.

On admission, detailed history and clinical examination of the patients was done.

Diagnosis of acute myocardial infarction was made by two out of three criteria:

Chest pain, ECG changes, serum cardiac biomarkers. Sgarbossa criteria ${ }^{13}$ is used for electrocardiographic manifestations of ischaemia in the setting of left bundle branch block. The outcomes observed were heart failure as determined by highest Killip's class, ${ }^{14}$ Arrhythmias, Regional wall motion abnormality (RWMA), Left ventricular ejection fraction (LVEF) and Death.

The data collected was analysed according to the appropriate statistical methods to reach a conclusion.

\section{Statistical Analysis}

The statistical software SPSS Ver 21 was used. Mean and standard deviation was calculated. Comparison between case and control was done using ' $\mathrm{t}$ ' test and chi-square test. The values of $\mathrm{p}<0.05$ were considered as significant.

\section{RESULTS}

A total of sixty patients of acute myocardial infarction were enrolled for study, out of which 30 patients presented as acute myocardial infarction with bundle branch block and 30 patients presented as acute myocardial infarction without bundle branch block.

The mean age in study Group A was $56.03 \pm 12.69$ years, whereas in study Group B mean age was $55.60 \pm 11.37$ years. The mean age amongst LBBB, RBBB and TFB was $62.65 \pm$ 12.37 years, $46.50 \pm 5.54$ years and $60.33 \pm 11.89$ years respectively.

Mean CPK MB (U/L) in Group A was $255.56 \pm 56$ and in Group B was $175 \pm 13.59$, thus mean CPK MB was higher in study group and statistically significant $(\mathrm{p}=0.002)$.

In Group A 4 (13.33\%), 8 (33.33\%), 10 (33.33\%) and 8 (26.66\%) patients presented in Killip class 1, 2, 3 and 4 respectively. In Group B 10 (33.33\%), 12 (40\%), 6 (20\%) and $2(6.66 \%)$ patients were in Killip class 1, 2, 3 and 4 respectively ( $p=0.047$, statistically significant).

2D echocardiography revealed that in Group A, 21 (70\%) patients had regional wall abnormality and $9(30 \%)$ patients in Group B had regional wall motion abnormality. Thus, it was observed that patients with bundle branch block had more regional motion abnormality as an echocardiographic finding and was significant $(\mathrm{p}=0.02)$.

2D echocardiography was done to measure left ventricular ejection fraction. In Group A mean LVEF was $33.93 \pm 6.63$ and in Group B mean LVEF was $46.16 \pm 4.09$, which was statistically significant $(\mathrm{p}=0.001)$.

Atrial fibrillation was observed in $5(16.66 \%)$ patients in Group A compared to 1 (3.33\%) in Group B, complete AV block was observed in 5 (16.66\%) patients in Group A and no patient in Group B developed complete AV block. Ventricular fibrillation was not observed in Group A and 1 (3.33\%) patient in Group B had developed ventricular fibrillation. Thus, it was observed that arrhythmias were more common in patients of acute myocardial infarction presenting with bundle branch block than in patients of acute myocardial infarction without bundle branch block and was statistically significant $(\mathrm{p}=0.05)$.

Mortality in Group A was 9 (21\%) patients as compared to $2(6.66 \%)$ patients in Group B. This study showed that mortality rate was higher in patients of acute myocardial infarction with bundle branch block $(p=0.020)$.

\begin{tabular}{|c|c|c|}
\hline Parameter & Group A $(n=30)$ & Group B $(n=30)$ \\
\hline Killip class I & $4(13.3 \%)$ & $10(33.33 \%)$ \\
\hline Killip class II & $8(26.66 \%)$ & 12 (40.0\%) \\
\hline Killip class III & $10(33.33 \%)$ & $6(20.0 \%)$ \\
\hline Killip class IV & $8(26.66 \%)$ & $2(6.66 \%)$ \\
\hline $\begin{array}{l}\text { Regional wall motion } \\
\text { abnormality }\end{array}$ & $21(70.0 \%)$ & $9(30.0 \%)$ \\
\hline Atrial fibrillation & $5(16.66 \%)$ & $1(3.33 \%)$ \\
\hline Ventricular fibrillation & 0 & $1(3.33 \%)$ \\
\hline Complete AV block & $5(16.66 \%)$ & 0 \\
\hline Mortality & $9(30.0 \%)$ & $2(6.66 \%)$ \\
\hline
\end{tabular}

\begin{tabular}{|c|c|c|}
\hline Parameter & $\begin{array}{c}\text { Group A } \\
(\mathbf{n = 3 0 )}\end{array}$ & $\begin{array}{c}\text { Group B } \\
(\mathbf{n = 3 0 )}\end{array}$ \\
\hline Mean age (years) & $56.03 \pm 12.69$ & $55.60 \pm 11.37$ \\
\hline LVEF (\%) & $33.93 \pm 6.63$ & $46.16 \pm 4.09$ \\
\hline CPK-MB (U/L) & $255.56 \pm 24.79$ & $175.00 \pm 13.59$ \\
\hline \multicolumn{2}{|c|}{ Table 2. Mean of Various Parameters Observed } \\
\hline
\end{tabular}

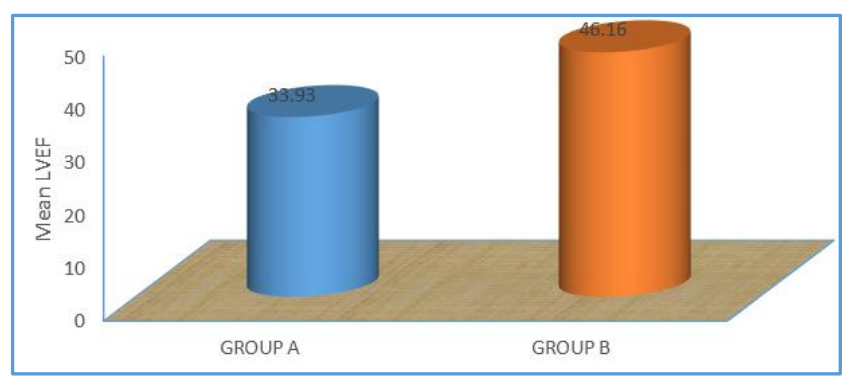

Figure 1. Left Ventricular Ejection Fraction

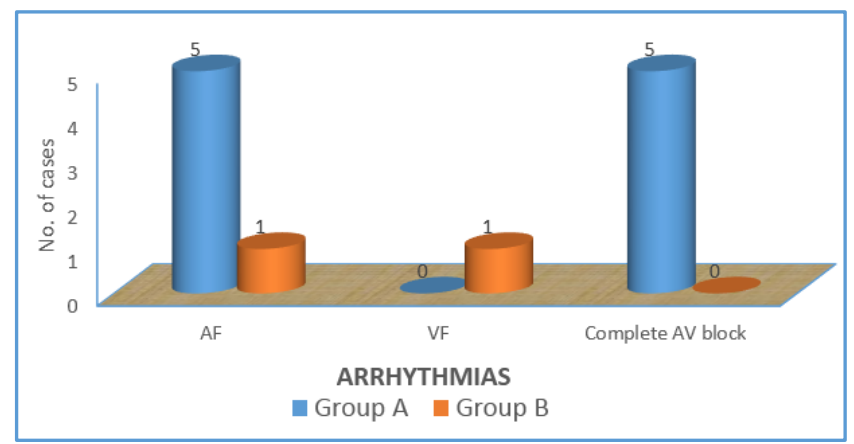

Figure 2. Arrhythmias

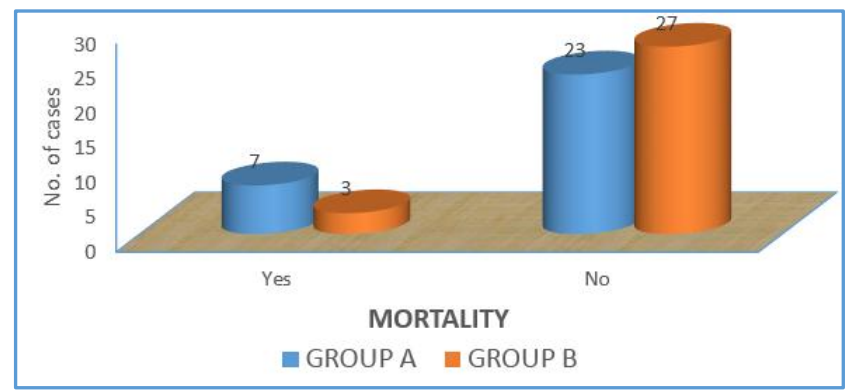

Figure 3. Mortality 


\section{DISCUSSION}

Complete left or right bundle branch block at presentation has been reported to occur in $1 \%$ to $15 \%$ of patients with acute myocardial infarction and it has been associated with increased risk for short- and long-term death. ${ }^{3}$ In our study among BBB 23 (76.66\%) patients had LBBB, 04 (13.33\%) patients had RBBB and $3(10 \%)$ patients had TFB. In a previous study, the overall incidence of bundle-branch block was found to be $23.6 \%$.(15) In this study the mean age was $62.65 \pm 12.37$ years in patients of LBBB, while RBBB had a mean age of $46.50 \pm 5.54$ years. In a previous study done on 132 patients of LBBB, whose mean age was $61.65 \pm 13.02$ years. ${ }^{16}$ In our study, mean $\mathrm{CPK} \mathrm{MB}$ in Group A was $255.56 \pm 24.79$ and mean $\mathrm{CPK}$ MB in Group B was $175.00 \pm 13.59$. In another study, mean CPK MB in patients of AMI with BBB was $256 \pm 143$ and mean CPK MB in patients of AMI without BBB was $167 \pm 75.17$ In this study, in Group A 4 (13.33\%) patients presented in Killip class 1, 8 (26.66\%) patients were in class 2, $10(33.33 \%)$ were in class 3 and 8 (26.66\%) presented in class 4. In Group B 10 (33.33\%), 12 (40\%), 6 (20.00\%) and 2 (6.66\%) patients presented in Killip class 1, 2, 3 and 4 respectively. Daniela T had concluded that among patients of AMI without BBB $22.2 \%$ belonged to class 1, 37.8\% belonged to class 2, $26.7 \%$ belonged to class 3 and $13.2 \%$ were in class 4 . Amongst patients with AMI with BBB $12.1 \%$ belonged to class $1,26.4 \%$ to class $2,34 \%$ to class 3 and $27.5 \%$ to class 4.18 Melgarejo MA et al in their study showed that mean LVEF amongst patients with AMI with BBB was $33 \pm 10$ while in patients of AMI without BBB was $47 \pm$ 12,19 whereas in our study 2D echo was done for all patients. In Group A, mean LVEF was $33.93 \pm 6.63$ and Group B mean LVEF was $46.16 \pm 4.09$. Morbidity and mortality are due to the development of arrhythmias during myocardial infarction. Left ventricular (LV) dysfunction was common in the majority of patients with ventricular tachycardia (VT), ventricular fibrillation (VF) and second or third degree atrioventricular (AV) block. ${ }^{20} \mathrm{BBB}$ usually expresses a large infarction frequently accompanied by heart failure, complete AV block, arrhythmia and high mortality rates. ${ }^{21}$ In our study, in Group A AF was observed among $5(16.66 \%)$ patients, 5 (16.66\%) patients developed complete AV block and in Group B, $1(3.33 \%)$ patient had AF, 1 (3.33\%) patient developed VF and complete $\mathrm{AV}$ block was not observed in any of the patients. Hreybe $\mathrm{H}$ et al conducted a study of 21,807 patients of AMI. The mortality rate in their study was $9.3 \% .{ }^{22}$ In the present study, mortality was observed in $9(30 \%)$ patients in Group A and $2(6.66 \%)$ patients in Group B. Altalhi HK et al studied that the $26 \%$ mortality rate in the patients of bundle branch block is significantly higher than the $12 \%$ mortality for control subjects without bundle branch block. ${ }^{17}$

\section{CONCLUSION}

Acute myocardial infarction with bundle branch block had more in-hospital morbidity and mortality. Incidence of heart failure and arrhythmias were more in patients of acute myocardial infarction with bundle branch block. 2D echocardiography revealed more regional wall motion abnormality and lower left ventricular ejection fraction amongst patients of acute myocardial infarction with bundle branch block.

\section{ACKNOWLEDGEMENT}

At the outset I endow my sincere thanks to my supervisor, my mentor and my guide, Dr. Tejinder Sikri, MD, Professor, Department of Medicine, Government Medical College. This work could not have been possible without his immense efforts and guidance. I am thankful to my Seniors, Colleagues and Juniors of Department of Medicine, Government Medical College, Amritsar without whose willing and wholehearted cooperation and optimistic and loving attitude it would have been impossible to complete this work the way it has been. My words are not sufficient to express my gratitude to all my patients who peep behind every typed word of this project and without whose cooperation this project would not have seen the light of the day.

\section{REFERENCES}

[1] Anderson JL, Morrow DA. Acute myocardial infarction. New England Journal of Med 2017;376(21):2053-64.

[2] Ghuran AV, Camm AJ. Ischemic heart disease presenting as arrhythmias. Br Med Bull 2001;59:193210.

[3] Go AS, Barron HV, Rundle AC, et al. Bundle-branch block and in-hospital mortality in acute myocardial infarction. National Registry of Myocardial Infarction 2 Investigators. Ann Internal Med 1998;129(9):690-7.

[4] Fahy GJ, Pinski SL, Miller DP, et al. Natural history of isolated bundle branch block. The American Journal of Cardiol 1996;77(14):1185-90.

[5] Nimetz AA, Shubrooks SJ, Hutter AM, et al. The significance of bundle branch block during acute myocardial infarction. Am Heart J 1975;90(4):439-44.

[6] Hollander G, Nadiminti V, Lichstein E, et al. Bundle branch block in acute myocardial infarction. Am Heart J 1983;105(5):738-43.

[7] Brilakis ES, Wright RS, Kopecky SL, et al. Bundle branch block as a predictor of long-term survival after acute myocardial infarction. Am J Cardiol 2001;88(3):205-9.

[8] Shlipak MG, Go AS, Frederick PD, et al. Treatment and outcomes of left bundle-branch block patients with myocardial infarction who present without chest pain. National Registry of Myocardial Infarction 2 Investigators. J Am Coll Cardiol 2000;36(3):706-12.

[9] Friesinger GC, Smith RF. Old age, left bundle branch block and acute myocardial infarction: a vexing and lethal combination. J Am Coll Cardiol 2000;36(3):7136.

[10] Sgarbossa EB, Pinski SL, Topol EJ, et al. Acute myocardial infarction and complete bundle branch block at hospital admission: clinical characteristics and outcome in the thrombolytic era. GUSTO-I Investigators. Global Utilization of Streptokinase and tPA [tissue-type plasminogen activator] for Occluded Coronary Arteries. J Am Coll Cardiol 1998;31(1):10510.

[11] Moreno AM, Alberola AG, Tomas JG, et al. Incidence and prognostic significance of right bundle branch block in patients with acute myocardial infarction receiving thrombolytic therapy. Int J Cardiol 1997;61(2):135-41. 
[12] Shlipak MG, Lyons WL, Go AS, et al. Should the electrocardiogram be used to guide therapy for patients with left bundle branch block and suspected myocardial infarction? JAMA 1999;281(8):714-19.

[13] Thygesen K, Alpert JS, Jaffe AS, et al. Third universal definition of myocardial infarction. European Heart J 2012;33(20):2551-67.

[14] Killip T, Kimball JT. Treatment of myocardial infarction in a coronary care unit. A two year experience with 250 patients. Am J Cardiol 1967;20(4):457-64.

[15] Newby KH, Pisano E, Krucoff MW, et al. Incidence and clinical relevance of the occurrence of bundle branch block in patients treated with thrombolytic therapy. Circulation 1996;94(10):2424-8.

[16] Bhardwaj R. Etiology and left ventricular functions in left bundle branch block-a prospective observational study. Journal of the Association of Physicians of India 2016;64(9):36-8.

[17] Altalhi HK, Fadhlullah AA, Abdalgbar AA. Clinical significance of bundle branch block complicating acute myocardial infarction at hospital admission. JMSCR 2017;05(03):19641-6.
[18] Daniela T. Clinical characteristics and prognosis significance of bundle-branch block (BBB) associated with acute myocardial infarction (AMI). Rom J Intern Med 1996;34(3-4):211-5.

[19] Melgarejo-Moreno A, Galcera-Tomas J, Garcia-Alberolam A. Prognostic significance of bundle-branch block in acute myocardial infarction: the importance of location and time of appearance. Clinical Cardiol 2001;24(5):371-6.

[20] Toshniwal SP, More RA, Kabara MV. Arrhythmias during the 1st week of acute myocardial infarction: an observational cross-sectional study. International Journal of Advanced Health Sci 2015;1(9):1-4.

[21] Klein RC, Vera Z, Mason DT. Intraventricular conduction in acute myocardial infarction: incidence, prognosis, and therapy. Am Heart J 1984;108(4 Pt 1):1007-13.

[22] Hreybe H, Saba S. Location of acute myocardial infarction and associated arrhythmias and outcome. Clinical Cardiol 2009;32(5):274-7. 